\title{
The usage of integral equations hereditary theories for calculating changes of measures of the theory of damage when exposed to repeated loads
}

\author{
Применение интегральных уравнений наследственных \\ теорий для расчета изменения мер теории поврежденности \\ при воздействии повторных нагрузок
}

\author{
N.P. Aleksandrova, \\ Siberian State Automobile And Highway \\ Academy, Omsk, Russia

\section{V.V. Chysow,} \\ Siberian State Automobile And Highway \\ Academy, Omsk, Russia
}

Key words: damage materials; asphalt pavement; continuity; damage; reload; strength criterion; plasticity condition

\author{
Канд. техн. наук, доцент \\ Н.П. Александрова, \\ Сибирская государственная автомобильно- \\ дорожная академия, г. Омск, Россия \\ аспирант В.В. Чусов, \\ Сибирская государственная автомобильно- \\ дорожная академия, г. Омск, Россия
}

\begin{abstract}
Ключевые слова: поврежденные материалы; асфальтобетонное покрытие; сплошность; поврежденность; повторная нагрузка; критерий прочности; условие пластичности
\end{abstract}

\begin{abstract}
The article gives an overview and analysis of the models of the damage accumulation in monolithic materials when exposed to prolonged and repeatedly applied load. The application of the principle of equivalence stress in the continuous and damage body allowed introducing into the strength criterion of Pisarenko-Lebedev and the three-parameter plasticity condition of Coulomb-Mohr the measures of the theory to accumulate damage in capacity of which the damage of Y.N. Rabotnova and the continuity of L.M. Kachanov are used. It was found that when exposed to repeated load, the process of the reduction of the continuity and the increase in the damage is hereditary. Therefore, to predict changes in these measures under the action of cyclic loads the integral equations of the theory of heredity are applied. This simulation was carried out in two ways. The essence of the first method is that the change of the damage and the continuity in the effects of a repeated stress is determined by the integral equations where the integrand functions are given by means of the degree of dependence. The integration of these functions allowed receiving generalizing logarithmic and exponential models to calculate the reduction of the continuity and the increase in the damage when subjected to cyclic loading. The second way is to apply to the calculation of the damage the principle of equivalence of the deformation or energy where a decrease in the elasticity modulus of the damaged body is described by an integral equation. It was demonstrated that the first method of the calculation of the measures of the theory of the damage accumulation is similar to the principle of equivalence of deformations. There is some brief information about the experimental technique to determine the measures of the theory of the damage accumulation by means of which the parameters of the generalized models for some asphalt concretes are set. The difference of the proposed methods to predict the changes of the damage from analogue is shown.
\end{abstract}

Аннотация. В статье выполнен обзор и анализ моделей накапливания повреждений в монолитных материалах при воздействии длительной и многократно прикладываемой нагрузки. Применение принципа эквивалентности напряжений в сплошном и поврежденном теле позволило ввести в критерий прочности Писаренко - Лебедева и трехпараметрическое условие пластичности Кулона - Мора меры теории накапливания повреждений, в качестве которых приняты поврежденность Ю.Н. Работнова и сплошность Л.М. Качанова. Установлено, что при воздействии повторных нагрузок процесс уменьшения сплошности и увеличения поврежденности носит наследственный характер. Поэтому для прогнозирования изменения этих мер в условиях воздействия циклических нагрузок применены интегральные уравнения наследственных теорий. Такое моделирование выполнено двумя способами. Суть первого метода состоит в том, что изменение поврежденности и сплошности в процессе воздействия повторных нагрузок определяется интегральными уравнениями, в которых подынтегральные функции заданы степенными зависимостями. Интегрирование этих функций позволило получить обобщающие логарифмические и степенные модели для расчета уменьшения сплошности и увеличения поврежденности при воздействии циклической нагрузки. Второй способ заключается в применении Aleksandrova N.P., Chysow V.V. The usage of integral equations hereditary theories for calculating changes of measures of the theory of damage when exposed to repeated loads. Magazine of Civil Engineering. 2016. No. 2. Pp. 69-82. doi: 10.5862/MCE.62.7. 
к расчету поврежденности принципа эквивалентности деформаций или энергетической эквивалентности, в которых уменьшение модуля упругости поврежденного тела описывается интегральным уравнением. Показано, что первый способ расчета мер теории накапливания повреждений аналогичен принципу эквивалентности деформаций. Приведены краткие сведения об экспериментальной методике определения мер теории накапливания повреждений, при помощи которой установлены параметры обобщающих моделей для некоторых асфальтобетонов. Показано отличие предлагаемых способов прогнозирования изменения поврежденности от аналогов.

\section{Introduction}

The damage, accumulated in the structure of road-building materials because of exposure to repeated load, has a significant effect on the characteristics of the stress strain state SSS. Because of increasing damage, the ability of a material to resist ductile and brittle fracture is reduced. Therefore, an important element of engineering of road constructions must be a solution that allows predicting an increase in the damage when subjected to repeated loads. This will allow determining more accurately the service life of the pavement and overhaul time, which will lead to a more efficient use of funding.

The account of the influence of a damage material structure on their SSS is carried out using the theory of the damage accumulation. There are two fundamental areas of the damage theory in mechanics, where the two measures are applied and various methods for their determination exist [1, 2]. Both directions have demand by professionals of the road sector and are used in the evaluation of the stress strain state (SSS). The essence of the approaches is to use one of the two measures, called the continuity of L.M. Kachanova $\psi$ and the damage of Y.N. Rabotnova $\omega$. For long-term and short-term cyclical loads, the developed methods to calculate these measures and these methods are different. The continuity is determined by the ratio of the stress in a solid $\sigma$ and damaged $\sigma$ s material, namely, $\psi=\sigma / \sigma_{s}\left(\sigma_{s} \geq \sigma\right)$, damage of $\omega$ find by the ratio of the total defect area $F_{s}$ to the geometric area of the completely intact section [6] $F$. Both measures are determined by formulas

$$
\psi=\frac{\sigma}{\sigma_{s}} ; \quad \omega=\frac{F_{s}}{F} .
$$

Because the stress in a continuous and damaged body can be expressed by the geometric area intact section and the area of the sample unoccupied defects, then between the continuity and the damage there is a relationship which can be expressed by the formula

$$
\omega+\psi=1 ; \quad \omega=1-\psi ; \quad \psi=1-\omega .
$$

The first expression (2) shows the difference in the parameters of the theory of the damage consisting in the fact that each of them characterizes the total relative area is occupied by the defects (this damage $\omega$ ), and - without defects (this continuity $\psi$ ). The sum of these parameters is equal to unity, i.e. the sum of these measures is none other than the geometric sectional area expressed as a unit. Two other expressions (2) make it possible to calculate the value of one parameter by the value of another characteristic. In the theory of the damage accumulation the principles of equivalence SSS damaged and solid bodies is applied. The principle of equivalence stress follows from the first formula dependencies (1). According to this principle, you can define the components of the stress tensor of the damaged body $\sigma_{\mathrm{ij}} \omega$ via the components of the stress tensor $\sigma_{\mathrm{ij}}$ solid body. This calculation is performed according to the formula [2]

$$
\sigma_{i j \omega}=\frac{\sigma_{i j}}{1-\omega}=\frac{\sigma_{i j}}{\psi}
$$

Since the dependence (3) allows us to calculate any component of the stress tensor of the damaged body, it is possible to any characteristic of this tensor to submit multiplication of the similar characteristics to a solid body and the parameters theory of the damage. This implies that using the dependence (3) allows deducing the analytical or empirical strength criteria of damaged bodies. Most of the original strength criteria of damaged bodies were produced mainly for metals in the 70-90 years of XX century [4-9], but they are being applied and modified only today [10-15]. Let us note that the introduction of the continuity or the damage in the criteria of strength and plasticity conditions of solid bodies allows receiving their modification, which can be used in the calculation of damage bodies [3].

Other principles of equivalence of damage theories are designed to determine the measures through the parameters of the physical and mechanical properties of materials. Considering the strain equivalence

Александрова Н.П., Чусов В.В. Применение интегральных уравнений наследственных теорий для расчета изменения мер теории поврежденности при воздействии повторных нагрузок // Инженерно-строительный журнал. 2016. №2(62). С. 69-82. 
principle, note that the deformation of the damaged body $\varepsilon_{D}$ in a simple state of stress, such as uniaxial compression, can be calculated according to the formulas [2];

$$
\varepsilon_{D}=\frac{\sigma}{(1-\omega)} \cdot \frac{1}{E} ; \quad \varepsilon_{D}=\frac{\sigma}{E_{D}},
$$

Where $E$ и $E_{D}$ - elasticity (Young's) modules undamaged and damaged material, Pa.

The equating dependence (4) and performing transformation, we obtain

$$
E_{D}=E \cdot(1-\omega) ; \quad \omega=1-\frac{E_{D}}{E} ; \quad \psi=\frac{E_{D}}{E} .
$$

Thus, the damage and the continuity is defined by the ratio of the elastic module damaged and a continuum medium. Experts positively evaluate the deformation approach and a widely used representation (5) [16 - 18]. Moreover, in a number of publications they indicate that the score change of elastic modulus is the most convenient to determine the damage both for metals [19, 20] and for composites [21 - 23].

Later another postulate known as the principle of energy equivalence [24 is introduced] and the depending (5) has undergone modification. According to this principle, the damage is determined via the ratio elastic moduli of the damaged body and undamaged environment, but in a different expression, which has the form $[24,25]$

$$
\omega=1-\sqrt{\frac{E_{D}}{E}} . \quad \psi=\sqrt{\frac{E_{D}}{E}} .
$$

Of course, the choice of dependencies between (5) and (6) should be based on experimental data. The data of N.I. Karpenko [26] obtained for concrete and reinforced concrete allow us to make a choice in favor of expressions (5).

Substituting the relations (5) or (6) in a principle equivalence of stress (3) allows for the modification of the expression so that the stresses in the damaged body are a function of a component tensor of a solid body and the elastic module of damaged and undamaged environment. From a creep theory it follows that the elastic strain is a function of time. This means that the elastic modulus can be represented by a function of time, but inversely proportional to the aftereffect function (the retardation deformation). Mathematical formulas describing the time variation of the elastic modulus of asphalt concrete are introduced in the paper [27]. In the calculations of road constructions, the reduction in the elastic modulus when exposed to repeated loadings describes the function number of the applied loads. Therefore, under the influence of a single prolonged and short-term repeatedly applied load, the modulus of elasticity is determined by a variety of ways, through a function of time and the number of loads. In the theory of the damage accumulation, the definition of its measures under the influence of such loads is also different. Table 1 shows some models

\begin{tabular}{|c|c|}
\hline Author & Formula \\
\hline $\begin{array}{l}\text { L. M. Kachanov, } \\
\text { A. S. Shesterikov }\end{array}$ & $\begin{array}{l}\qquad v_{1}=\frac{d \omega}{d t}=C_{1} \cdot\left(\frac{\sigma_{i j}}{1-\omega}\right)^{m} ; \quad v_{2}=\frac{d \omega}{d t}=C_{2} \cdot\left(\frac{\sigma_{i j}}{1-\omega}\right)^{m}, \\
\text { where } C_{1}, C_{2} \text { и } m \text { - material parameters. }\end{array}$ \\
\hline Y. N. Rabotnov & $\begin{array}{l}\qquad v_{3}=\frac{d \omega}{d t}=C_{3} \cdot\left(\frac{\sigma_{i j}}{1-\omega}\right)^{m} \cdot \omega^{a}, \\
\text { where } C_{3}, m \text { и } a-\text { material parameters. }\end{array}$ \\
\hline John Lemaitre & $\begin{array}{l}\qquad v_{4}=\frac{d \omega}{d t}=C_{4} \cdot\left(\frac{\sigma_{i j}}{1-\omega}\right)^{m} \cdot \frac{1}{1-\omega^{b}} \\
\text { where } C_{4}, m \text { и } b-\text { material parameters. }\end{array}$ \\
\hline V. P. Golub, A. V. Romanov & $\begin{array}{c}\qquad v_{5}=\frac{d \omega}{d t}=C_{5} \cdot\left(\frac{\sigma_{i j}}{1-\omega}\right)^{m} \cdot\left(\frac{1}{1-\omega}\right)^{f\left(\sigma_{i j}\right)} \\
\text { where } C_{5}, m-\text { material parameters; } f\left(\sigma_{\mathrm{ij}}\right)-\text { the stress function. }\end{array}$ \\
\hline
\end{tabular}
describing the kinetics of the creep damage.

Table 1. Accumulation models of the creep damage [1]

Aleksandrova N.P., Chysow V.V. The usage of integral equations hereditary theories for calculating changes of measures of the theory of damage when exposed to repeated loads. Magazine of Civil Engineering. 2016. No. 2. Pp. 69-82. doi: 10.5862/MCE.62.7. 
Note: In formulas from the Table 1 instead of the original designation $\sigma$ [1] authors used $\sigma \mathrm{ij}$, emphasizing that in accordance with the principle of equivalence stress, the function of grow stress $\sigma$ can be spread to any component of the stress tensor $\sigma \mathrm{ij}$ and the entire tensor as a whole.

From analysis of formulas from the Table 1 follows that in the process of the emergence of new experimental data and increase the knowledge about accumulation in material damage during the creep, the authors were forced to complicate the function. Such complication of functions of damage is similar to the complication of the rheological creep functions and relaxation.

The hypothesis of damage summation is applied to calculate the damage from the effects of cyclic loading. We know three basic hypotheses: a linear summation of damage (the Palmgren - Miner principle), a bilinear summation (the S.S. Manson principle) and a non-linear accumulation of damage (the Richard Newmark principle). These hypotheses were proposed long time ago [28 - 30], but they are widely used at present [31 - 35]. Moreover, the principle of a linear summation used in the Russian Federation [31 - 33] while bilinear or nonlinear summations are used in other countries [34, 35]. The graphic illustration of the summation of the principles shown in Fig. 11.

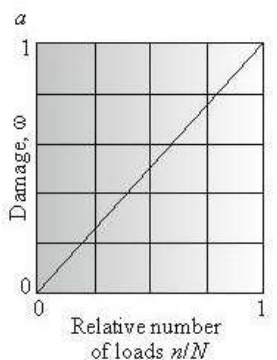

of loads $n / N$

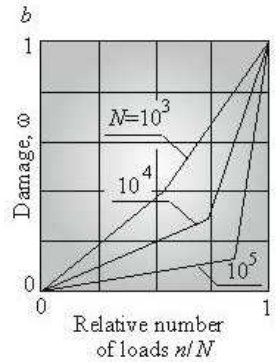

of loads niN

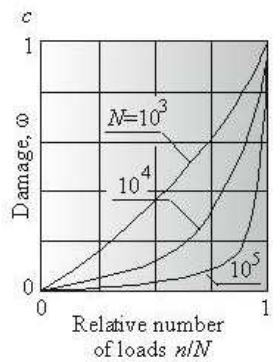

of loads $n / N$

Fig. 1. Principles of damage summation in the calculation of damage: a - a linear summation; $\mathbf{b}$ - a bilinear sum; $\mathrm{c}$ - a nonlinear summation

The formula describing a linear summation of damage is widely used in the works of Russian specialists, for example, [31, 32] a well-known model of a bilinear summation [29, 36, 37]. A nonlinear dependence to calculate the damage have different varieties. It results in the selection of the model applied to the material, It should be supported in an experimental way or it is necessary to develop a new nonlinear model for testing material.

Concluding the review of the literature, let us point out the problem areas used to calculate the asphalt concrete pavement and road pavement bases. Firstly, the layers of road clothes of monolithic materials are traditionally calculated according to the criterion of resistance to stretching of the bending, the basis of which lies the first theory of strength. Although it is known that it incorrectly evaluates the ability of a material to resist destruction. The specialists of the road sector made extensive studies of the effect of fatigue [32, 33] and the porosity at the strength of asphalt concrete [38], but the search for a new strength criterion was not fulfilled. Secondly, road surveys show that at high summer temperatures the drawdown on asphalt [39] and the surface rut, accompanied by bulging coating along the edge of strip rolling are formed [40]. The mechanism for this behavior of monolithic coating can be explained by the fact that with increasing temperature, asphalt loses its ability to run on a bend. Increasing the temperature at a certain value leads to the fact that a vertical deformation appears in the plate of asphalt. In connection with this data, one can assume that at even greater increase temperature, the asphalt works in triaxial compression conditions throughout the thickness of the layer, i.e. at these temperatures the bendability is completely lost. Such conditions of work are not taken into account in the normative criteria. It is assumed that the coating works in a pure bending. So the normative methods of the calculation of the asphalt concrete pavement should be supplemented with the terms of plasticity discrete medium, for example, the criterion of Coulomb-Mohr or it modifications, designed to evaluate the shear strength of discrete materials and soils. Continuity or damage must be entered in these criteria.

\section{The statement of purpose and objectives of the study}

The analysis of the problem allows us to formulate the purpose of the study, which consists in the improvement of the calculation methods of road constructions by introducing continuity and damage in

\footnotetext{
${ }^{1}$ In the work of our colleagues, the damage accumulates under the influence of cyclic loads, usually denoted by $D$ (from the English. Damage). For uniformity of notation in Fig. 1 and hereinafter referred to as the authors use the symbol $\omega$.

Александрова Н.П., Чусов В.В. Применение интегральных уравнений наследственных теорий для расчета изменения мер теории поврежденности при воздействии повторных нагрузок // Инженерно-строительный журнал. 2016. №2(62). С. 69-82.
} 
strength criteria and taking into account changes of the measures of the theory of material damage when subjected to repeated loads.

To achieve this goal it is necessary to solve the problem:

1. Enter the measures of continuity and damage to modify the strength criteria and ductility of the asphalt concrete for the calculation coatings and bases on the tensile strength and flexural shear stability.

2. Find the representations to calculate change for continuity $\psi$ and damage $\omega$ when subjected to repeated loads.

\section{Methods}

We use the expression (3), to take into account the strength criteria and plasticity in terms of the measures of the damage theory, which allows calculating the stress tensor of a damaged body through a similar tensor of a solid body. Operating with of the tensor components of stress of the damaged body, you can get the representation to calculate the characteristics of this tensor. Table 2 shows the formula for the calculation of the principal stresses and their characteristics determined by the stress state of the damaged body.

Table 2. Characteristics of the stress state of the damaged body

\begin{tabular}{|c|c|}
\hline $\begin{array}{c}\text { Name } \\
\text { characteristics }\end{array}$ & Formula \\
\hline 1 & 2 \\
\hline Main stress $\sigma_{1 \omega}, \sigma_{2 \omega}, \sigma_{3 \omega}$ & $\begin{aligned} \sigma_{1 \omega}= & \frac{\sigma_{1}}{1-\omega}=\frac{\sigma_{1}}{\psi} ; \quad \sigma_{2 \omega}=\frac{\sigma_{2}}{1-\omega}=\frac{\sigma_{2}}{\psi} ; \sigma_{3 \omega}=\frac{\sigma_{3}}{1-\omega}=\frac{\sigma_{3}}{\psi} \\
& \text { where } \sigma_{1}, \sigma_{2} \text { и } \sigma_{3}-\text { the principal stresses in the intact body. }\end{aligned}$ \\
\hline $\begin{array}{l}\text { The maximum shear stresses } \\
\qquad \tau_{\max \omega}\end{array}$ & $\begin{array}{l}\quad \tau_{\max \omega}=\frac{\tau_{\max }}{1-\omega}=\frac{\tau_{\max }}{\psi} ; \tau_{\max \omega}=\frac{\sigma_{1}-\sigma_{3}}{2 \cdot(1-\omega)}=\frac{\sigma_{1}-\sigma_{3}}{2 \cdot \psi} \\
\text { where } \tau_{\max }-\text { maximum shear stress in the intact body. }\end{array}$ \\
\hline $\begin{array}{l}\text { Octahedral normal } \\
\sigma_{\text {oct } \omega} \text { and the tangent } \tau_{\text {oct } \omega} \text { stress }\end{array}$ & $\begin{array}{c}\sigma_{\mathrm{oct} \omega}=\frac{\sigma_{\mathrm{oct}}}{1-\omega}=\frac{\sigma_{\mathrm{oct}}}{\psi} ; \tau_{\mathrm{oct} \omega}=\frac{\tau_{\mathrm{oct}}}{1-\omega}=\frac{\tau_{\mathrm{oct}}}{\psi} \\
\text { where } \sigma_{\mathrm{oct}} \boldsymbol{\eta} \tau_{\mathrm{oct}}-\text { octahedral normal and tangential stresses in the intact body. }\end{array}$ \\
\hline $\begin{array}{l}\text { The intensity of the normal } \sigma_{i \omega} \text { and } \\
\text { the tangent } \tau_{i \omega} \text { stress }\end{array}$ & $\begin{array}{l}\qquad \sigma_{i \omega}=\frac{\sigma_{i}}{1-\omega}=\frac{\sigma_{i}}{\psi} ; \tau_{i \omega}=\frac{\tau_{i}}{1-\omega}=\frac{\tau_{i}}{\psi} \\
\text { where } \sigma_{i} и \tau_{i}-\text { the intensity of the normal and shear stress (intensity R. Mises) in } \\
\text { the intact body. }\end{array}$ \\
\hline $\begin{array}{l}\text { Invariants of the stress tensor (first } \\
\left.l_{1 \omega} \text {, second } I_{2 \omega} \text { and third } I_{3 \omega}\right)\end{array}$ & $\begin{array}{l}\qquad I_{1 \omega}=\frac{I_{1}}{1-\omega}=\frac{I_{1}}{\psi} ; I_{2 \omega}=\frac{I_{2}}{(1-\omega)^{2}}=\frac{I_{2}}{\psi^{2}} ; I_{3 \omega}=\frac{I_{3}}{(1-\omega)^{3}}=\frac{I_{3}}{\psi^{3}}, \\
\text { where } I_{1}, I_{2} \text { и } I_{3}-\text { the first, second and third invariants of the stress tensor of the } \\
\text { intact body. }\end{array}$ \\
\hline $\begin{array}{l}\text { The second invariant of the stress } \\
\text { deviator }\end{array}$ & $J_{2 \omega}=\frac{1}{(1-\omega)^{2}} \cdot\left(I_{2}-\frac{1}{3} \cdot I_{1}^{2}\right)=\frac{1}{\psi^{2}} \cdot\left(I_{2}-\frac{1}{3} \cdot I_{1}^{2}\right)$ \\
\hline $\begin{array}{l}\text { The third invariant of the stress } \\
\text { deviator }\end{array}$ & $\begin{aligned} J_{3 \omega} & =\frac{1}{(1-\omega)^{3}} \cdot\left(I_{3}-\frac{1}{3} \cdot I_{1} \cdot I_{2}+\frac{2}{27} \cdot I_{1}^{3}\right)= \\
& =\frac{1}{\psi^{3}} \cdot\left(I_{3}-\frac{1}{3} \cdot I_{1} \cdot I_{2}+\frac{2}{27} \cdot I_{1}^{3}\right) .\end{aligned}$ \\
\hline
\end{tabular}

Aleksandrova N.P., Chysow V.V. The usage of integral equations hereditary theories for calculating changes of measures of the theory of damage when exposed to repeated loads. Magazine of Civil Engineering. 2016. No. 2. Pp. 69-82. doi: 10.5862/MCE.62.7. 
Entering measures of the damage theory into strength criteria and plasticity condition can be performed by replacing the stress state of a solid body on tensor characteristics of the damaged body. According to the formulas from Table 2, these characteristics are the functions or damage or continuity and characteristics of the stress tensor of the intact body. Using a modified condition plasticity, obtained in [41], and entering the dependence to calculate the principal stresses of the damaged body expressed via of damage in it, we get

$$
\frac{1}{2 \cdot\left(1-\omega_{N}\right)} \cdot\left[\sigma_{1} \cdot\left(\frac{1-\sin \varphi}{1+\sin \varphi}\right)^{d}-\left(\frac{1+\sin \varphi}{1-\sin \varphi}\right)^{d} \cdot \sigma_{3}\right]=c,
$$

where $\omega N$ and $\psi N$ - damage and continuity after exposure to N number of design loads, $M U$.; $\sigma 1$ and $\sigma 3$ the maximum and minimum principal stresses arising in the asphalt concrete at high summer temperatures causing it triaxial throughout the thickness of the layer, $\mathrm{MPa} ; \varphi$ and $\mathrm{c}$ - the angle of an internal friction and the adhesion of asphalt concrete that are the setting limit of the direct Coulomb - Mohr, degrees (radians) and MPa respectively; $d$ - the parameter entered in one of the conditions of entry forms of Coulomb - Mohr [41] taking into account the amount of the deformation of the sample, which is taken as the limit when triaxial material is used.

If the criteria (7) damage replaces the continuity, the equation of a limiting condition takes the form

$$
\frac{1}{2 \cdot \psi_{N}} \cdot\left[\sigma_{1} \cdot\left(\frac{1-\sin \varphi}{1+\sin \varphi}\right)^{d}-\left(\frac{1+\sin \varphi}{1-\sin \varphi}\right)^{d} \cdot \sigma_{3}\right]=c \text {. }
$$

When $d=0,5$ and $\omega N=0$ or $1 \psi N=$ modified plasticity condition (7) and (8) takes the form of one of the known forms of recording of the original terms of the plasticity of Coulomb-Mohr [41]. When $d=0$ and $\omega \mathrm{N}=\psi \mathrm{N}=0$ or 1 , conditions (7) and (8) become identical to the third theory of strength. When $0 \leq \mathrm{d} \leq 0,5$ and $\omega \mathrm{N}=0$ or $\psi \mathrm{N}=1$ this condition takes the form of a modified criterion [41]. Thus, the difference between (7) and (8) from prototype [41] consists in the registration impact of damage, progressing with increasing of repeated impact loads on the ability of materials to resist shear. This difference causes the novelty of the modified criteria (7) and (8).

When modifying the strength of the criteria used to calculate the asphalt layers on the fatigue tensile bending, take into account the opinion of O.T. Batrakova2, who believed that the first theory of strength applied to a standard method of design is sufficient to replace the original criterion of $\mathrm{O}$. Mora. It is known that the Pisarenko-Lebedev criterion summarizes the original criterion of $O$. Mora in the event of the stress state $\sigma 1>\sigma 2>\sigma 3$, acquiring its form when $\sigma 1>\sigma 2=\sigma 3$. Table 3 shows the original and the modified criteria of Pisarenko - Lebedev.

Table 3. Equations of limit states for the original criterion of Pisarenko-Lebedev and its modifications, taking into account the measures of the damage theory.

\begin{tabular}{|l|l|c|}
\hline \multirow{2}{*}{$\begin{array}{c}\text { The author of the original } \\
\text { criterion }\end{array}$} & \multicolumn{1}{|c|}{ The equation of limit state for: } \\
\cline { 2 - 3 } & \multicolumn{1}{|c|}{ the original criterion } & \multicolumn{1}{c|}{$\begin{array}{c}\text { the criterion modified by authors of the } \\
\text { publication }\end{array}$} \\
\hline Pisarenko, Lebedev [43] & $\begin{array}{l}\chi \cdot \sigma_{\mathrm{i}}+(1-\chi) \cdot \sigma_{1}=R_{\mathrm{t}} ; \\
\chi=R_{\mathrm{t}} / R_{\mathrm{cs}}, \\
\text { where } \chi \text { - a material parameter, } \\
\text { associated with compressive } \\
\text { strength and tensile Rcs and Rt }\end{array}$ & $\frac{1}{1-\omega_{N}} \cdot\left[\chi \cdot \sigma_{\mathrm{i}}+(1-\chi) \cdot \sigma_{1}\right]=R_{\mathrm{t}} ;$ \\
\hline
\end{tabular}

${ }^{2}$ Batrakov O.T. Strengthening non-rigid pavements. - M.: Transport, 1985. - 144 p.

Александрова Н.П., Чусов В.В. Применение интегральных уравнений наследственных теорий для расчета изменения мер теории поврежденности при воздействии повторных нагрузок // Инженерно-строительный журнал. 2016. №2(62). С. 69-82. 
Analyzing the original criterion of Pisarenko-Lebedev for the stress state $\sigma 1>\sigma 2=\sigma 3$, easy to get $\sigma i=\sigma 1-\sigma 3$, whereby this criterion takes the form

$$
\frac{R_{\mathrm{t}}}{R_{\mathrm{cs}}} \cdot\left(\sigma_{1}-\sigma_{3}\right)+\left(1-\frac{R_{\mathrm{t}}}{R_{\mathrm{cs}}}\right) \cdot \sigma_{1}=R_{\mathrm{t}}
$$

Opening the braces, we get

$$
\sigma_{1}-\frac{R_{\mathrm{t}}}{R_{\mathrm{cs}}} \cdot \sigma_{3}=R_{\mathrm{t}}
$$

The formula (10) is the equation of limit state of the original criterion of $O$. Mora. It is used to calculate the materials in tension. If in the condition (10) performs the replacement of the tensile strength $\mathrm{Rt}$ to the tensile strength flexural $\mathrm{Rf}$ and enter the parameters of the damage theory, we obtain the equation

$$
\frac{1}{1-\omega_{N}} \cdot\left(\sigma_{1}-\frac{R_{\mathrm{f}}}{R_{\mathrm{cs}}} \cdot \sigma_{3}\right)=R_{\mathrm{f}} ; \quad \frac{1}{\psi_{N}} \cdot\left(\sigma_{1}-\frac{R_{\mathrm{f}}}{R_{\mathrm{cs}}} \cdot \sigma_{3}\right)=R_{\mathrm{f}} .
$$

The equation of limit state in the form (11) is introduced in the document3 and is tested while designing the asphalt concrete pavement of roads of gas fields YaNAO. Thus, the publication of the given materials has practical significance. Note that the criterion (11) compared to the standard criteria of instructions has a higher accuracy. Consequently the Pisarenko-Lebedev criterion (Table 3), summarizing the theory of Mora, allows solving problems with greater accuracy, spreading (11) in the states of stress, characterized by the principal stresses $\sigma 1>\sigma 2>\sigma 3$. Here, the authors emphasize the novelty of the modified criterion in Table 3 and its accuracy compared with the equation (11) proposed and tested earlier.

The obtained modified plasticity condition (7) and (8), as well as the strength criteria in Table 3 and (11) require solutions allowing predicting the change in the measures of the damage theory in the process of re-load applications.

The data of the experiments show that in the process of reloads decrease the continuity and growth of damage because fatigue processes are hereditary. That is, the value of the continuity and damage observed when exposed to $\mathrm{n}$ load, due to the history of the application of all previous load. Since the process of reducing the continuity and growth of damage proceeds in conjunction with the fatigue and accumulation of strain, the basis of the integral expressions of the exponential function can be used. Then the kernel of integral equations is necessary to present power functions

$$
\begin{array}{ll}
\Delta \omega=a \cdot n^{-1} ; & \Delta \psi=-a \cdot n^{-1} ; \\
\Delta \omega=b \cdot n^{c} ; & \Delta \psi=-b \cdot n^{c}
\end{array}
$$

where $\Delta \omega$ and $\Delta \psi$ - respectively, the increment of damage and continuity of the $\mathrm{n}$ impact of load; $a, b$ and $c$ - coefficients taking into account the level of the stress state and the type of material.

Make an expression (12) and fulfill their integration, we obtain

$$
\omega_{N}=\omega_{0}+a \cdot \int_{1}^{N} n^{-1} d n=\omega_{0}+a \cdot \ln N
$$

where $\omega 0$ - the magnitude of damage, corresponding to the initial state.

$$
\psi_{N}=\psi_{0}-a \cdot \int_{1}^{N} n^{-1} d n=\psi_{0}-a \cdot \ln N
$$

\footnotetext{
${ }^{3}$ Aleksandrov A.S. and others. The calculation of non-rigid pavements such as roads gas fields of the Yamal-Nenets Autonomous District on the strength criteria. - Omsk: Publishing house SibADI, 2014. - P. 49 - 51.

Aleksandrova N.P., Chysow V.V. The usage of integral equations hereditary theories for calculating changes of measures of the theory of damage when exposed to repeated loads. Magazine of Civil Engineering. 2016. No. 2. Pp. 69-82. doi: 10.5862/MCE.62.7.
} 
where $\psi_{0}$ - the value of continuity corresponding to the initial state.

Taking as integrands of (13) and performing the integration, we obtain the sedate model of decreasing the continuity and growth of damage with an increase in the number of loading effects

$$
\begin{aligned}
& \omega_{N}=\omega_{0}+b \cdot \int_{1}^{N} n^{c} d n=\omega_{0}+b \cdot \frac{N^{c+1}-1}{c+1} . \\
& \psi_{N}=\psi_{0}-b \cdot \int_{1}^{N} n^{c} d n=\psi_{0}-b \cdot \frac{N^{c+1}-1}{c+1},
\end{aligned}
$$

Let us take the hypothesis of the initial state, according to which the material to repeated load application considered solid and having no damage whereby $\omega_{0}=0$ and $\psi_{0}=1$. Thus, the hypothesis of the initial state allows ignoring pores, microcracks and other defects that remain in the material after the manufacture thereof specimen or structure. In this case, take into account the damage produced only from the effects of repeated loads. In this case, expressions (14) - (17) take the form

$$
\begin{gathered}
\omega_{N}=a \cdot \ln N ; \quad \Psi_{N}=1-a \cdot \ln N . \\
\omega_{N}=b \cdot \frac{N^{c+1}-1}{c+1} ; \quad \Psi_{N}=1-b \cdot \frac{N^{c+1}-1}{c+1} .
\end{gathered}
$$

Analyzing the dependence (18) and (19) it is easy to see that with the increase in the number of repeated stress, the damage is rising and continuity is falling. In addition, in these dependencies the principle formulas are stored (1), whereby the sum of these measures is one, and each of them can be determined by the difference of unit and the other opposing measures.

Let us consider the second option to solve the problem based on the withdrawal of submission to calculate the elasticity modulus of the damaged body. At the same time, we note that the modulus of elasticity can be secant, tangent and piecewise linear (see. Fig. 2).
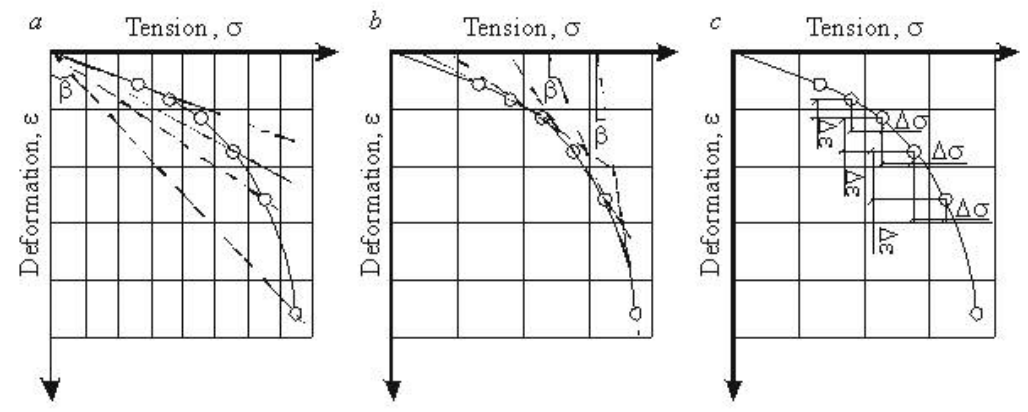

Fig. 2 Way of the detection and classification of the elastic module: a - secant modulus; $b$ - tangent modulus; $c$ - piecewise linear module.

In calculating changes of the damage or discontinuities caused by exposure to the repeated loads, it is possible to adopt any of these modules, but according to (5) or (6) substitute the value of the elastic modulus characterizing the deformation of the first's straight segments schedule.

Александрова Н.П., Чусов В.В. Применение интегральных уравнений наследственных теорий для расчета изменения мер теории поврежденности при воздействии повторных нагрузок // Инженерно-строительный журнал. 2016. №2(62). С. 69-82. 


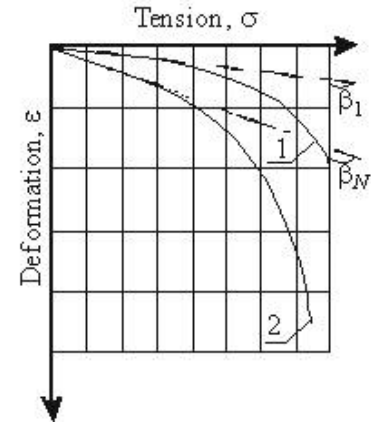

Fig. 3. - The scheme to determine the damage and continuity when subjected to repeated loading: 1 and 2 - respectively strain curves after number of stress $n=1$ and $\mathbf{n}=\mathbf{N}$

Figure 3 shows the scheme of the definition measures of the theory of damage accumulation. Curve 1 is a plot of stress-strain after a single application of a shortterm load. Curve 2 is similar to the dependence, but for the material tested multiple load applications with the number $\mathrm{n}$ $=\mathrm{N}$. Note that two experiments must be conducted to construct deforming curves shown in Figure 1. The first experiment is that the sample is subjected to repeated loads with a different number of applications (for example, $n=1$, $\mathrm{n}=10, \mathrm{n}=102, \mathrm{n}=103, \mathrm{n}=104, \mathrm{n}=105, \mathrm{n}=106 \ldots \mathrm{n}=$ $\mathrm{N})$. After performing this procedure, (the sample tested by monotonically increasing load and builds), the plots similar to those are shown in Figure 3 . If $\mathrm{N}$ is the limiting number, then all the other curves are located between the lines 1 and 2. In each graph, determine the endpoint of the first line segment, which is connecting the origin of coordinates. Figure 3 shows the compound in dotted rays. The same Figure shows the angles of rays, which coincide with straight line segments to the deformation axis. The arctangent of these angles determine the value of the modulus of elasticity corresponding to a certain number of re-load. Consequently, when exposed to repeated load, dependencies (5) and (6) can expedient written as

$$
\omega=1-\frac{E_{D N}}{E_{1}} \psi=\frac{E_{D N}}{E_{1}},
$$

where $E_{1}$ and $E_{D N}$ - the elastic module of the conventionally an undamaged material, determined under the influence of a short-term load, and the damaged material, determined after the application of $\mathrm{N}$ load.

If for the calculation of the elastic modulus we use integral equations of the theory of heredity, and the increment of the modulus of elasticity of the load with the number $n$, the power equation will have the form

$$
\Delta E_{D}=-b \cdot n^{c} .
$$

Then an integral equation and the result of integration will be in the form

$$
E_{D_{N}}=E \cdot\left(1-b \cdot \int_{1}^{N} n^{c} d n\right)=E \cdot\left(1-b \cdot \frac{N^{c+1}-1}{c+1}\right),
$$

Substituting (22) into the formula (5) and (6), we obtain

$$
\omega=b \cdot \frac{N^{c+1}-1}{c+1} ; \quad \omega=1-\sqrt{1-b \cdot \frac{N^{c+1}-1}{c+1}} .
$$

The continuity is determined analogously or by using the properties recorded by the formulas (2). While comparing the addiction (19) with the first expression (23), it is easy to verify the identity of these formulas. This means that the first method of the calculation of the measures of the theory of the damage accumulation proposed and used by us in the calculations (12) - (19) is similar to the principle of the equivalence of deformations. These methods lead to the same formulas with the same integrand. The principle of energy equivalence leads to another dependency and thus it differs from the first method we have demonstrated.

\section{Results and Discussion}

Comparing the proposed methods to calculate the damage parameter of asphalt concrete with similar [27, 42-45], we note that in the works of our colleagues a function of time for calculating the change in the damage or the elasticity modulus of asphalt concrete is used. The proposed method operates the functions of the number of the design loads. This makes our models different and give them advantage. Aleksandrova N.P., Chysow V.V. The usage of integral equations hereditary theories for calculating changes of measures of the theory of damage when exposed to repeated loads. Magazine of Civil Engineering. 2016. No. 2. Pp. 69-82. doi: 10.5862/MCE.62.7. 
This is due to the fact that the mathematical models [27, 42-45] to account for the number of loads require the application of the theory of the similarity of deformation of the material at creep and exposed of cyclic loading. The essence of this theory is the functions of the time. The duration of the sustained load is replaced by a product of the exposure time of one cyclic load and their number. This method requires the determination of the coefficient correcting the difference of a deformation creep curve from the deformation accumulated from repeated loads. Thus, there is a need to perform two tests. The first experiment is a test for the creep of asphalt concrete, and the second test is optional and it is used to determine the depending of the deformation on the number of repeated loads.

Of course, the definition of the parameters of the models is the task of experimental studies. In order to perform it we have developed a method, which includes the rules of the manufacture laboratory samples, a planning experiment and a statistical analysis of the results. The presentation of the experimental procedure and its results are extensive and it requires writing another article. In this publication, we stress that we have created this technique and have performed some tests on the fatigue bending beam resulting in the determination of the values of the parameter a, used in the model (18) for some types of asphalt concrete. The results of these and other experimental studies as well as the implementation methods we will try to explain in a subsequent publication. In this article, we pay attention to beneficial differences of the developed experimental techniques from analogue, present the values of the coefficients of the model (18) and compare the results of the calculation of the damage to the experimental data. Figure 4a shows a traditional scheme of the test asphalt beam on bending [46]. In the study of the influence of damage on the fatigue of the asphalt concrete at the bottom (in the tensile stress zone), such beam arrange a slot [46 - 48]. Because of it, the girder becomes large and according to the opinion of the author's work [46], it is difficult to manufacture it in the laboratory. To address this shortcoming we have applied a laboratory test developed by prof. V.V. Sirotyuk, which allows producing 3 asphalt beams $10 \mathrm{~cm}$ thick and $60 \mathrm{~cm}$ long each. Figure $4 b$ shows the stand.
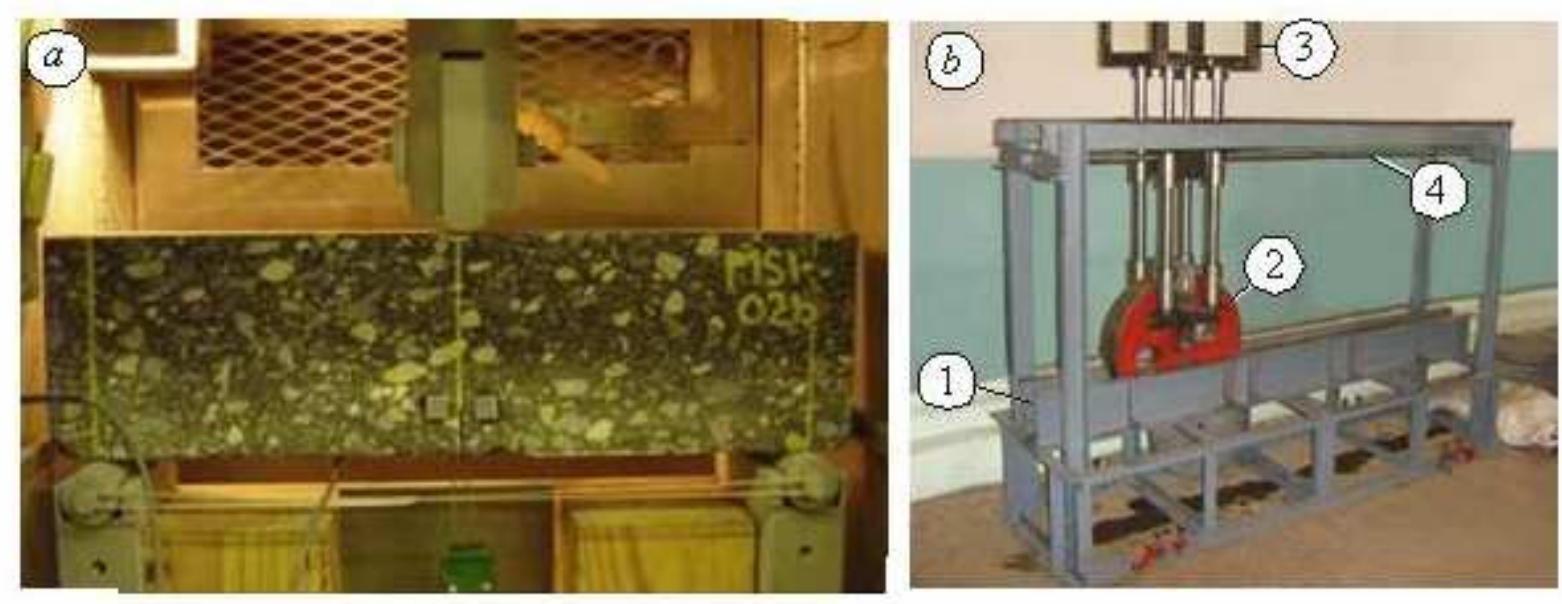

\section{Fig. 4. Illustration of equipment to test asphalt beams: a - test beam when subjected to cyclic loading [46]; b - stand of prof. V.V. Sirotyuk for the production of asphalt concrete beams}

Produced asphalt concrete beams were tested in the device of dynamic loading made when using the drawings by prof. V.V. Sirotyuk. The device was placed in a climate chamber where the temperature of asphalt beams is kept while testing by means of the cyclic load. Under these conditions, the beam was exposed to a specified number of loads, the value of which is identical and corresponds to the force with which in asphalt coating having tensile stresses corresponding design load A1. Fig. 5 shows the experimental data on the dependence of damage and continuity of the number of repeated loads, as well as data to calculate formulas (19) with $b=0.0218$ and $c=-0.884$.

Александрова Н.П., Чусов В.В. Применение интегральных уравнений наследственных теорий для расчета изменения мер теории поврежденности при воздействии повторных нагрузок // Инженерно-строительный журнал. 2016. №2(62). С. 69-82. 


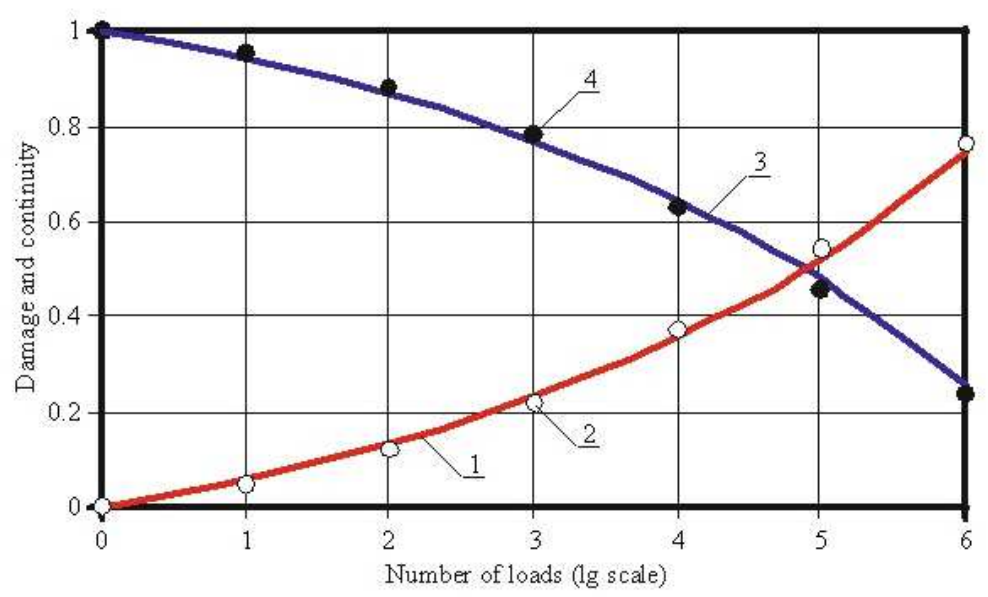

Fig. 5. The dependence of the damage and the continuity of the asphalt concrete at a bend on the number of cyclic loads: 1 and 2 - respectively, calculated and experimental values of the damage; 3 and 4 - respectively, the calculated and experimental values of continuity

From the analysis of the data shown in Figure 5 it is seen that the proposed mathematical model (19) with the correct selection of the parameters $b$ and $c$ is adequate to experimental data, and thus it can be applied in the design of the asphalt concrete pavement of roads.

\section{Conclusions}

Summing up the materials, the authors may formulate a number of conclusions and define the scope and prospects for their future research.

1. A modified plasticity condition (7), (8) and strength criteria (see. Tab. 3), taking into account the effect of the accumulation of asphalt damage have been proposed. These criteria make it possible to perform the calculation of the structural layers of the pavement on the shear resistance and tensile fatigue from bending.

2. The application of integral equations of the heredity theory obtained logarithmic and exponential mathematical models predicting changes damage of Y.N. Rabotnova and continuity of L.M. Kachanova when subjected to repeated loads.

3. Our further research will focus on the development of an experimental method, which allows estimating the value of the continuity measures and the damage of the asphalt concrete at flexural uniaxial and triaxial compression under conditions of repeatedly applied loads.

4. While planning the experiment temperature and granulometry asphalt concrete can be taken as significant factors, bitumen content thereof, as well as the magnitude of the stresses. Tests of the asphalt concrete with variation of these parameters allow developing the multiparameter mathematical model to calculate the coefficient as a function (18), (19) and (23).

\section{Aknowledgement}

The authors are grateful to Dr. Technical Sciences, prof. V.V. Sirotyuk and Cand. Tehn. Sciences G.M. Levashov (Department "Design of roads" SibADI) for the provided installation that allowed applying cyclic loads of different frequencies, as well as tips and tricks for this equipment.

\section{Литература}

1. Lemaitre J. A Course on Damage Mechanics. Jane Lamaitre, Rodrigue Desmorat. Verlag Berlin Heidelberg: Springer, 2005. $380 \mathrm{p}$.

2. Сосновский Л. Концепции поврежденности материалов / Л. Сосновский, С. Щербаков. // Вісник ТНТУ. 2011. Спецвипуск - частина 1. С.14-23.

3. Александрова Н.П., Александров А.С., Чусов В.В. 3. Aleksandrova N.P., Aleksandrov A.S., Chusov V.V. Модификация критериев прочности и условий Modifikatsiya kriteriyev prochnosti i usloviy plastichnosti pri 
пластичности при расчетах дорожных одежд // Вестник СибАДИ. 2015. № 4. С. $47-54$.

4. Shima S., Oyane M. Plasticity theory for porous metals International Journal of Mechanical Sciences. 1976. Vol. 18. Pp. $285-291$

5. Gurson A.L. Continuum theory of ductile rupture by void nucleation and growth; I. Yield criteria and flow rules for porous ductile media. J. Eng. Materials Technol., 1977. Vol. 99. No. 1 Pp. 2-15.

6. Tvergaard V. Influence of voids on shear band instabilities under plane strain conditions. Int. J. Fracture. 1981. Vol. 17. Pp. 389-407.

7. Tvergaard V., Needleman A. Analysis of the cup-cone fracture in a round tensile bar. Acta Metall. 1984. Vol. 32. Pp. 157-169.

8. Lee J.H., Oung J. Yield functions and flow rules for porous pressure-dependent strain-hardening polymeric mate-rials. $J$. Appl. Mech. 2000. Vol. 67. No. 2. Pp. 288-297.

9. Sofronis P., McMeeking R.M. Creep of power-law material containing spherical voids. J. Appl. Mech. 1992. Vol. 59. No. 2 Pp. 88-95.

10. Vaz Jr. M. et all. Considerations on parameter identification and material response for Gurson-type and Lemaitre-type constitutive models. International Journal of Mechanical Sciences. 2016. Vol. 106. Pp. 254-265.

11. Vaz Jr. Considerations on identification of damage parameters: a case study. XIII International Conference on Computational Plasticity: fundamentals and applications (COMPLAS 2015). Barcelona, 1-3 September 2015 Pp. 194 -203.

12. Barbu L.G.,Large scale validation of a new isotropic hardening law for the barcelona plastic damage model unde ultra low cycle fatigue conditions. XIII International Conference on Computational Plasticity: fundamentals and applications (COMPLAS 2015). Barcelona, 1-3 September 2015. Pp. 248-259.

13. Li S. Meshfree Method for Ductile Fracture with Modified Gurson's Model. 19th Structural Dynamics and Materials Conference. 04 - 07 April 2011, Denver, Colorado. 2011. Pp 1-11.

14. Li S., Simonsen C.B. Meshfree Simulations of Ductile Crack Propagations. International Journal for Computational Methods in Engineering Science and Mechanics. 2005. Vol. 6 (1). Pp. 1 -19 .

15. Бенин А.В., Семенов А.С., Семенов С.Г., Мельников Б.Е. Конечно-элементное моделирование процессов разрушения и оценка ресурса элементов автодорожного моста с учетом коррозионных повреждений // Инженерностроительный журнал. 2012. №7. С. 32 - 42.

16. Ambroziak A., Klosowski P. Survey of modern trends in analysis of continuum damage mechanics. Task Quarterly. 2006. No 4, 437 - 454 .

17. Granda Marroquin L.E. et al. Cumulative Damage Evaluation under Fatigue Loading. Applied Mechanics and Materials. 2008. Vol. 13-14. Pp 141-150.

18. Tsiloufas S.P., Plaut R.L. Ductile Fracture Characterization for Medium Carbon Steel Using Continuum Damage Mechanics. Materials Sciences and Applications. 2012. No. 3. Pp. $745-755$

19. Lemaitre J., Dufailly J. Damage measurements Engineering Fracture Mechanics. 1987. Vol. 28. No. 516. Pp. $643-661$.

20. Kim S., Kim W. A progressive damage modeling based on the continuum damage mechanics and its finite element analysis. Journal of Applied Mechanics. 1994. Vol. 61. Pp. $45-$ 53. raschetakh dorozhnykh odezhd [Modification of the criteria of strength and ductility conditions in the calculation of road pavement]. Vestnik SibADI. 2015. No 4. Pp. 47 - 54. (rus)

4. Shima S., Oyane M. Plasticity theory for porous metals. International Journal of Mechanical Sciences. 1976. Vol. 18. Pp. $285-291$.

5. Gurson A.L. Continuum theory of ductile rupture by void nucleation and growth; I. Yield criteria and flow rules for porous ductile media. J. Eng. Materials Technol., 1977. Vol. 99. No. 1. Pp. 2-15.

6. Tvergaard V. Influence of voids on shear band instabilities under plane strain conditions. Int. J. Fracture. 1981. Vol. 17. Pp. 389-407.

7. Tvergaard V., Needleman A. Analysis of the cup-cone fracture in a round tensile bar. Acta Metall. 1984. Vol. 32. Pp. 157-169.

8. Lee J.H., Oung J. Yield functions and flow rules for porous pressure-dependent strain-hardening polymeric mate-rials. J. Appl. Mech. 2000. Vol. 67. No. 2. Pp. 288-297.

9. Sofronis P., McMeeking R.M. Creep of power-law material containing spherical voids. J. Appl. Mech. 1992. Vol. 59. No. 2 Pp. 88-95.

10. Vaz Jr. M. et all. Considerations on parameter identification and material response for Gurson-type and Lemaitre-type constitutive models. International Journal of Mechanical Sciences. 2016. Vol. 106. Pp. 254-265.

11. Vaz Jr. Considerations on identification of damage parameters: a case study. XIII International Conference on Computational Plasticity: fundamentals and applications (COMPLAS 2015). Barcelona, 1-3 September 2015. Pp. $194-203$.

12. Barbu L.G.,Large scale validation of a new isotropic hardening law for the barcelona plastic damage model under ultra low cycle fatigue conditions. XIII International Conference on Computational Plasticity: fundamentals and applications (COMPLAS 2015). Barcelona, 1-3 September 2015. Pp. 248-259.

13. Li S. Meshfree Method for Ductile Fracture with Modified Gurson's Model. 19th Structural Dynamics and Materials Conference. 04 - 07 April 2011, Denver, Colorado. 2011. Pp 1-11.

14. Li S., Simonsen C.B. Meshfree Simulations of Ductile Crack Propagations. International Journal for Computational Methods in Engineering Science and Mechanics. 2005. Vol. 6 (1). Pp. 1 -19 .

15. Benin A.V., Semenov A.S., Semenov S.G., Melnikov B.Ye. Konechno-elementnoye modelirovaniye protsessov razrusheniya i otsenka resursa elementov avtodorozhnogo mosta s uchetom korrozionnykh povrezhdeniy [Finite element simulation of fracture processes and the evaluation of the resource elements of the highway bridge in view of corrosion damage]. Magazine of Civil Engineering. 2012. No 7. Pp. 32 42. (rus)

16. Ambroziak A., Klosowski P. Survey of modern trends in analysis of continuum damage mechanics. Task Quarterly. 2006. No 4, 437 - 454

17. Granda Marroquin L.E. et al. Cumulative Damage Evaluation under Fatigue Loading. Applied Mechanics and Materials. 2008. Vol. 13-14. Pp 141 - 150.

18. Tsiloufas S.P., Plaut R.L. Ductile Fracture Characterization for Medium Carbon Steel Using Continuum Damage Mechanics. Materials Sciences and Applications. 2012. No. 3. Pp. 745 - 755 .

19. Lemaitre J., Dufailly J. Damage measurements. Engineering Fracture Mechanics. 1987. Vol. 28. No. 516. Pp. $643-661$.

Александрова Н.П., Чусов В.В. Применение интегральных уравнений наследственных теорий для расчета изменения мер теории поврежденности при воздействии повторных нагрузок // Инженерно-строительный журнал. 2016. №2(62). С. 69-82. 
21. Delaet M., Lataillade J., Wol C. Intralaminar shear loading eects on the damage process of multiply composites at impact rates. In: International Conference on Mechanical and Physical Behaviour of Materials under Dynamic. Journal de Physique IV. Les EÂ ditions de Physique and DYMAT, 1994. Pp. 213 - 218.

22. Lemaitre J., Leckie F., Sherman D. Crazing of laminates. European Journal of Mechanics, A/Solids 1992. Vol.11(3). Pp. $289-304$.

23. Tang C., Plumtree A. Damage mechanics applied to polymers. Engineering Fracture Mechanics 1994. Vol. 49(4). Pp. $499-508$.

24. Alves M., Yu J,, Jones $\mathrm{N}$. On the elastic modulus degradation in continuum damage mechanics. Computers and Structures. 2000. Vol. 76. Pp. $703-712$.

25. Shen J. et al. Material damage evaluation with measured microdefects and multiresolution numerical analysis. International Journal of Damage Mechanics. 2014, Vol. 23(4) Рp. $537-566$.

26. Карпенко Н.И. Общие модели механики железобетона / Н.И. Карпенко - М.: Стройиздат, 1996. - 416 с.

27. Кириллов А.М., Завьялов М.А. Моделирование изменения модуля упругости асфальтобетона при нагружении / А.М. Кириллов, // Инженерно-строительный журнал. - 2015. № 2. - С. $70-76$.

28. Miner M.A. Cumulative damage in fatigue. Journal of Applied Mechanics. 1945, No. 12, Pp. 159 - 164.

29. Manson S.S., Freche J.C., Ensign C.R. Application of a double linear damage rule to cumulative fatigue. ASTM STP. 1967. Pp. 384-412.

30. Richart F.E., Newmark N.M. A hypothesis for determination of cumulative damage in fatigue. Proc. ASTM 48, 1968. Pp. 767-800.

31. Petinov S.V., Guchinsky R.V., Sidorenko V.G. Damage identity in fatigue assessment of structures. Magazine of Civil Engineering, 2016, No.1. Pp. $82-88$.

32. Углова Е.В. Прогнозирование усталостной долговечности асфальтобетонных покрытий // Транспортное строительство. 2008. № 11. С. 13-17.

33. Дровалева О.В. Оценка усталостной долговечности асфальтобетона в условиях воздействия циклических нагрузок при интенсивном скоростном транспортном потоке // Известия высших учебных заведений. Строительство. 2009. № 11-12. C. $65-70$.

34. Liu Y., Mahadevan S. Stochastic fatigue damage modeling under variable amplitude loading. International Journal of Fatigue. 2007, Vol. 29. Pp 1149- 1161.

35. Zhu S-P., et all. Probabilistic modeling of damage accumulation for time-dependent fatigue reliability analysis of railway axle steels. Journal Rail and Rapid Transit. 2015, Vol. 229 (1). Pp $23-33$.

36. Manson, S.S., Halford, G.R. Practical implementation of the double linear damage rule and damage curve ap-proach for treating cumulative fatigue damage. Int. J. Fatigue. 1981. Vol. 17. Pp. $169-192$.

37. Goodin, E, Kallmeyer A, Kurath P. Evaluation of nonlinear cumulative damage models for assessing HCF/LCF interactions in multiaxial loadings. Proceedings of the 9th national turbine engine high cycle fatigue (HCF) conference. March 16-19, Pinehurst, NC; 2004.

38. Кириллов А.М., Завьялов М.А. Интерпретация свойств асфальтобетона в дорожном покрытии // Строительные материалы. 2015. № 4. С. 87 - 92.

39. Кириллов А.М. Просадки асфральтобетонных покрытий и способы их предотвращения / А.М. Кириллов // Дороги России. 2014. № 6. С. $101-106$.
20. Kim S., Kim W. A progressive damage modeling based on the continuum damage mechanics and its finite element analysis. Journal of Applied Mechanics. 1994. Vol. 61. Pp. $45-$ 53.

21. Delaet M., Lataillade J., Wol C. Intralaminar shear loading eects on the damage process of multiply composites at impact rates. In: International Conference on Mechanical and Physical Behaviour of Materials under Dynamic. Journal de Physique IV. Les EÂ ditions de Physique and DYMAT, 1994. Pp. 213 - 218.

22. Lemaitre J., Leckie F., Sherman D. Crazing of laminates. European Journal of Mechanics, A/Solids 1992. Vol.11(3). Pp. $289-304$.

23. Tang C., Plumtree A. Damage mechanics applied to polymers. Engineering Fracture Mechanics 1994. Vol. 49(4). Pp. $499-508$.

24. Alves $\mathrm{M}$., $\mathrm{Yu} \mathrm{J}$, Jones $\mathrm{N}$. On the elastic modulus degradation in continuum damage mechanics. Computers and Structures. 2000. Vol. 76. Pp. $703-712$.

25. Shen J. et al. Material damage evaluation with measured microdefects and multiresolution numerical analysis. International Journal of Damage Mechanics. 2014, Vol. 23(4) Pp. $537-566$.

26. Karpenko N.I. Obshchiye modeli mekhaniki zhelezobetona [The common model of mechanics of reinforced concrete]. Moscow: Stroyizdat, 1996. 416 p. (rus)

27. Kirillov A.M., Zavyalov M.A. Modelirovaniye izmeneniya modulya uprugosti asfaltobetona pri nagruzhe-nii [Modelling changes modulus of elasticity of asphalt concrete under load] Magazine of Civil Engineering. 2015. № 2. Pp. 70 - 76. (rus)

28. Miner M.A. Cumulative damage in fatigue. Journal of Applied Mechanics. 1945, No. 12, Pp. 159 - 164.

29. Manson S.S., Freche J.C., Ensign C.R. Application of a double linear damage rule to cumulative fatigue. ASTM STP. 1967. Pp. 384-412.

30. Richart F.E., Newmark N.M. A hypothesis for determination of cumulative damage in fatigue. Proc. ASTM 48, 1968. Pp. $767-800$

31. Petinov S.V., Guchinsky R.V., Sidorenko V.G. Damage identity in fatigue assessment of structures. Magazine of Civil Engineering, 2016, No.1. Pp. $82-88$.

32. Uglova Ye.V. Prognozirovaniye ustalostnoy dolgovechnosti asfaltobetonnykh pokrytiy [Prediction of fatigue life of asphalt concrete pavements]. Transportnoye stroitelstvo. 2008. No 11. Pp. 13-17. (rus)

33. Drovaleva O.V. Otsenka ustalostnoy dolgovechnosti asfaltobetona $\mathrm{v}$ usloviyakh vozdeystviya tsiklicheskikh nagruzok pri intensivnom skorostnom transportnom potoke [Estimation of fatigue life of asphalt concrete under the action of cyclic loads at intensive traffic flow speed]. Izvestiya vysshikh uchebnykh zavedeniy. Stroitelstvo. 2009. No 11-12. Pp. $65-$ 70. (rus)

34. Liu Y., Mahadevan S. Stochastic fatigue damage modeling under variable amplitude loading. International Journal of Fatigue. 2007, Vol. 29. Pp 1149 - 1161.

35. Zhu S-P., et all. Probabilistic modeling of damage accumulation for time-dependent fatigue reliability analysis of railway axle steels. Journal Rail and Rapid Transit. 2015, Vol. 229 (1). Pp $23-33$

36. Manson, S.S., Halford, G.R. Practical implementation of the double linear damage rule and damage curve ap-proach for treating cumulative fatigue damage. Int. J. Fatigue. 1981. Vol. 17. Pp. 169-192.

37. Goodin, E, Kallmeyer A, Kurath P. Evaluation of nonlinear cumulative damage models for assessing HCF/LCF interactions in multiaxial loadings. Proceedings of the 9th national turbine engine high cycle fatigue (HCF) conference. March 16-19, Pinehurst, NC; 2004.

Aleksandrova N.P., Chysow V.V. The usage of integral equations hereditary theories for calculating changes of measures of the theory of damage when exposed to repeated loads. Magazine of Civil Engineering. 2016. No. 2. Pp. 69-82. doi: 10.5862/MCE.62.7. 
40. Герцог В.Н., Долгих Г.В., Кузин В.Н. Расчет дорожных одежд по критериям ровности. Часть 1. Обоснование норм ровности асфальтобетонных покрытий // Инженерностроительный журнал. 2015. № 5. С. $45-57$.

41. Александров А.С., Калинин А.Л.Совершенствование расчета дорожных конструкций по сопротивлению сдвигу Часть 1. Учет деформаций в условии пластичности Кулона - Мора // Инженерно-строительный журнал. 2015. № 7. С. 4 -17 .

42. Im, S., You, T., Ban, H., Kim, Y.-R. Multiscale testinganalysis of asphaltic materials considering viscoelastic and viscoplastic deformation. International Journal of Pavement Engineering. 2015. 15 p. Article in Press.

43. Dai, Q., Sadd, M.H., You Z. A micromechanical finite element model for linear and damage-coupled viscoelastic behaviour of asphalt mixture. Int. J. Numer. Anal. Meth Geomech. 2006. Vol. 30. Pp. $1135-1158$.

44. Aragão, F.T.S., Kim, Y.-R., Lee, J., Allen, D.H. Micromechanical Model for Heterogeneous Asphalt Concrete Mixtures Sub-jected to Fracture Failure. Journal of Materials in Civil Engineering. 2011. 23 (1). Pp. 30-38.

45. Zelelew H.M. Simulation of the permanent deformation of asphalt concrete mixtures using discrete element method (dem). PhD Thesis. Washington state university, Department of Civil and Environmental Engineering. 2008. 271 p.

46. Kim, Yong-Rak. Cohesive Zone Model to Predict Fracture in Bituminous Materials and Asphaltic Pavements: State-of-theArt Review. International Journal of Pavement Engineering. 2011. Vol. 12:4. Pp. $343-356$

47. Song, S.H., Paulino, G.H., Buttlat, W.G., Simulation of crack propagation in asphalt concrete using an intrinsic co-hesive zone model. Journal of Engineering Mechanics. 2006. Vol. 132 (11). Pp. 1215-1223.

48. Wagoner, M.P., Buttlar, W.G., Paulino, G. H. Development of a single-edge notched beam test for asphalt concrete mixtures. Journal of Testing and Evaluation. 2005. Vol. 33 (6) Pp. 452-460.

Наталья Павловна Александрова,

+7(913)6164212; эл. почта: nata26.74@mail.ru; Василий Владимирович Чусов, +7(3812)651563; эл. почта: chysow@gmail.com
38. Kirillov A.M., Zavyalov M.A. Interpretatsiya svoystv asfaltobetona $v$ dorozhnom pokrytii [Interpretation properties of asphalt in pavement]. Stroitelnyye materialy. 2015. No 4. Pp. 87 - 92. (rus)

39. Kirillov A.M. Prosadki asfaltobetonnykh pokrytiy i sposoby ikh predotvrashcheniya [Drawdowns asphalt concrete pavement and how to prevent them]. Dorogi Rossii. 2014. No 6. Pp. 101 - 106. (rus)

40. Gertsog V.N., Dolgikh G.V., Kuzin V.N. Raschet dorozhnykh odezhd po kriteriyam rovnosti. Chast 1. Obosnovaniye norm rovnosti asfaltobetonnykh pokrytiy [Calculation of pavements for flatness criteria. Part 1. Justification standards evenness of asphalt-concrete coatings]. Magazine of Civil Engineering. 2015. No 5. Pp. 45 - 57. (rus)

41. Aleksandrov A.S., Kalinin A.L. Sovershenstvovaniye rascheta dorozhnykh konstruktsiy po soprotivleniyu sdvigu. Chast 1. Uchet deformatsiy $v$ uslovii plastichnosti Kulona Mora [Improving the calculation of road constructions on the shear strength. Part 1. Accounting of of deformation in the condition of plasticity of Coulomb - Mohr]. Magazine of Civil Engineering. 2015. No 7. Pp. 4 - 17. (rus)

42. Im, S., You, T., Ban, H., Kim, Y.-R. Multiscale testinganalysis of asphaltic materials considering viscoelastic and viscoplastic deformation. International Journal of Pavement Engineering. 2015. 15 p. Article in Press.

43. Dai, Q., Sadd, M.H., You Z. A micromechanical finite element model for linear and damage-coupled viscoelastic behaviour of asphalt mixture. Int. J. Numer. Anal. Meth. Geomech. 2006. Vol. 30. Pp. $1135-1158$.

44. Aragão, F.T.S., Kim, Y.-R., Lee, J., Allen, D.H. Micromechanical Model for Heterogeneous Asphalt Concrete Mixtures Sub-jected to Fracture Failure. Journal of Materials in Civil Engineering. 2011. 23 (1). Pp. 30-38.

45. Zelelew H.M. Simulation of the permanent deformation of asphalt concrete mixtures using discrete element method (dem). PhD Thesis. Washington state university, Department of Civil and Environmental Engineering. 2008. 271 p.

46. Kim, Yong-Rak. Cohesive Zone Model to Predict Fracture in Bituminous Materials and Asphaltic Pavements: State-of-theArt Review. International Journal of Pavement Engineering. 2011. Vol. 12:4. Pp. 343 - 356.

47. Song, S.H., Paulino, G.H., Buttlat, W.G., Simulation of crack propagation in asphalt concrete using an intrinsic co-hesive zone model. Journal of Engineering Mechanics. 2006. Vol. 132 (11). Pp. 1215-1223.

48. Wagoner, M.P., Buttlar, W.G., Paulino, G. H. Development of a single-edge notched beam test for asphalt concrete mixtures. Journal of Testing and Evaluation. 2005. Vol. 33 (6). Pp. 452-460

Nataliy Aleksandrova, +7(913)6164212; nata26.74@mail.ru; Vasiliy Chysow, +7(3812)651563; chysow@gmail.com

() Александрова Н.П., Чусов В.В., 2016

Александрова Н.П., Чусов В.В. Применение интегральных уравнений наследственных теорий для расчета изменения мер теории поврежденности при воздействии повторных нагрузок // Инженерно-строительный журнал. 2016. №2(62). С. 69-82. 